\title{
PENINGKATAN PENGOLAHAN PAKAN USAHA SUSU KAMBING ETAWA DI KECAMATAN PERCUT SEI TUAN
}

\author{
Choms Gary Ganda Tua Sibarani ${ }^{1)}$, Suhairiani ${ }^{2)}$, Widya Arwita ${ }^{3)}$, \\ Adek Cerah Kurnia Azis ${ }^{4}$ \\ Universitas Negeri Medan \\ Gary.linacker@gmail.com
}

\begin{abstract}
ABSTRAK
Kegiatan Pengabdian kepada Masyarakat ini bertujuan untuk memperbaiki pembukuan keuangan mitra, menciptakan inovasi mesin pengolahan pakan dan buku penduan pembukuan keuangan usaha. Permasalahan yang tengah dihadapi oleh mitra dalam kegiatan pengabdian kepada masyarakat ini ada beberapa item yakninya: a). Sistem pembukuan keuangan pengolahan keuangan usaha bisa dikatakan masih tradisional karena tidak adanya perhitungan modal, laba, dan hal lain yang berhubungan dengan keuangan sebuah usaha dan b). Pegolahan pakan masih menggunakan tenaga manusia (manual). Adapun solusi yang diberikan dalam kegiatan pengabdian kepada masyarakat ini adalah mitra diberikan pelatihan, pendidikan, pendampingan, sosialisasi, dan penyerahan Teknologi Tepat Guna (TTG) mengenai permasalahan yang tengah dihadapi oleh mitra yaitunya a). tim pengabdi memberikan buku panduan pembukuan keuangan untuk penyelesaian permasalahan mitra dan b). penyerahan inovasi mesin pengolahan pakan ternak untuk penyelesaian masalah mitra dalam pengolahan pakan ternak. Metode yang digunakan dalam pelaksanaan program pengabdian kepada masyarakat ini yaitunya dengan melakukan pendekatan, maksud dari pendekatan ini, perolehan informasi awal hingga akhir proses kegiatan dilakukan dengan komunikasi secara langsung dan lewat alat komunikasi secara intensif antara mitra dengan tim pengabdi, sehingga pelaksanaan kegiatan dapat dilakukan secara terbimbing, yang tujuan utamanya untuk meningkatkan kesejahteraan mitra dalam mengelolah Usaha Kecil Menengah (UKM)nya, yaitunya usaha susu kambing etawa di Desa Kolam.
\end{abstract}

Kata kunci: Susu, Kambing, Etawa, Desa Kolam.

\begin{abstract}
This community service activity seeks to improve partners' financial, create feed processing machines dan bookkeeping financial book. The problems that are being questioned by partners in community service activities are sure items: a). The financial accounting system that manages finance can be completed is still traditional because there is no calculation of capital, profits, and other matters relating to the financials of a business and b). Processing is still using human power (manual). The solutions provided in this community service activity are partners who are given training, education, assistance, socialization, and the delivery of Appropriate Technology (TTG) on questions being discussed by the partners concerned a). The service team provides a financial bookkeeping manual to obtain partner approval and b). submission of animal feed processing machinery innovations to overcome the problems of partners in manual feed processing. The method used in the implementation of this community service program is by asking, for the purpose of this agreement, to request information beginning to the end of the activity process carried out by direct communication and through improved communication tools with partners with the service team, so that activities can be carried out. By guided, which aims to improve the welfare of parnert in managing her Small and Medium Enterprises (SMEs), namely the Etawa Goat milk business in Desa Kolam.
\end{abstract}

Kata kunci: Milk, Goat, Etawa, Desa Kolam.

\section{PENDAHULUAN}

Salah satu kampung tertua di Kecamatan Percut Sei Tuan, Kabupaten Deli Serdang adalah Kampung Kolam, Kampung Kolam didirikan kurang lebih
32 tahun yang lalu tepatnya pada tahun 1986, didirikan oleh seorang Ulama bernama Datuk Tengku Ulung. Seiring dengan berjalannya waktu Kampung Kolam berubah nama menjadi Desa 
Kolam. Desa menurut Undang-Undang Nomor 6 Tahun 2014 tentang "UU Desa" adalah "kesatuan masyarakat yang memiliki batas wilayah yang berwenang untuk mengatur dan mengurus urusan pemerintahan, kepentingan masyarakat setempat berdasarkan prakarsa masyarakat, hak asal usul, dan/ atau tradisi yang diakui dan dihormati dalam sistem pemerintahan Negara Kesatuan Republik Indonesia" (UU Desa Nomor 6, 2014).

Desa Kolam secara langsung berbatasan dengan Desa Saentis pada bagian Utara, sebelah Selatan dengan Desa Bandar Klippa, sebelah Barat dengan Desa Bandar Setia, dan dengan Desa Sidodali yang masuk ke dalam Kecamatan Batang Kuis pada bagian Timur.

Berdasarkan jumlah penduduk yang ada di Desa Kolam tersebut di atas memiliki beraneka ragam aktivitas mata pencaharian, ada yang bermatapencaharian sebagai petani/ berkebun, buruh bangunan/ buruh tani, berdagang/ berwirausaha, dan ada juga sebagai Pegawai Negeri Sipil (PNS)/ Pegawai/ Karyawan Swasta. beragamnya aktivitas ini merupakan kekayaan tersendiri yang dimiliki oleh Desa Kolam terhadap Sumber Daya Manusia (SDM) nya, maka dengan demikian kepala Desa Kolam Bapak Jupri Purwanto berkeinginan "Mewujudkan Desa Kolam yang Sejahtera" (Yuni, 2018:02).

Salah satu usaha yang telah dilakukan oleh pemerintahan Desa Kolam untuk kesejahteraan masyarakatnya yaitu dengan memberikan peluang berusaha untuk mengembangkan usaha atau membentuk usaha baru bagi masyarakatnya. Pemerintah Desa Kolam mensuport penuh perkembangan Usaha Kecil Menengah
(UKM) yang dikelolah oleh masyarakat untuk menjadi lebih kerkembang lagi, salah satu UKM yang berkemungkinan bisa lebih berkembang lagi yang ada di Desa Kolam adalah "USAHA SUSU KAMBING ETAWA" UKM ini dikelolah oleh Bapak "Sunimin" berlokasi di Jl. Mesjid, Gang Amal, No. 34. Desa Kolam, Kecamatan Percut Sei Tuan, Kabupaten Deli Serdang, Provinsi Sumatera Utara, Kode Pos 20371.

Bapak Sunimin sering mencatat pembukuan keuangan hasil dari penjualan susu menggunakan kertas bekas, terkadang kertas-kertas ini hilang karena lupa tempat meletakkannya, itupun tanpa ada hitungan yang berkelanjutan maksudnya kadang ada dan kadang tidak ada penghitungan, laba usahapun tidak jarang juga digunakan untuk keperluan lain seperti kebutuhan seharihari sehingga modal dan laba sering tidak jelas pembukuannya.

Usaha yang memiliki 1 (satu) orang karyawan ini, mengumpulkan pakan ternak kambing seperti singkong (ubi kayu), daun singkong, dan tongkol jagung dari Desa-Desa yang ada disekitaran Kecamatan Percut Sei Tuan, pakan ini di tampung di dekat kandang kambing kemudian diolah dengan cara memotong kecil-kecil secara manual, dalam 1 (satu) hari menghabiskan $20 \mathrm{~kg}$ singkong dan daun singkong, serta 25 $\mathrm{kg}$ tongkol jagung, proses pengolahan pakan ini menghabiskan waktu kurang lebih selama 2 (dua) jam, sementara jika pengolahan pakan tersebut dilakukan dengan menggunakan mesin, tentunya akan lebih efektif dan efesien dari segi waktu dan tenaga, dan tentunya dari segi kualitas pengolahan pakan yang baik bagi peningkatan kualitas dan kuantitas susu kambing etawa ini. Selanjutnya untuk produksi susu, usaha Bapak Sunimin mampu memproduksi 
30 (tiga puluh) bungkus berisi 200 (dua ratus) mili susu murni kambing etawa dalam 1 (satu) harinya, yang dibandrol dengan harga Rp. 10.000,- (sepuluh ribu rupiah) perbungkusnya.

Berdasarkan data di atas ada beberapa kasus yang harus dibenahi, pembenahan dapat dilakukan dengan mendatangkan pakar dari masingmasing kelemahan yang ada pada usaha Susu Kambing Etawa Bapak Sunimin, pakar tersebut bisa dari kalangan praktisi dan akademisi, yang lebih dititik beratkan kepada pembukuan keuangan, inovasi mesin pengolah pakan, pengetahuan tentang pengolahan pakan yang baik dan benar, dan dengan mendatangkan ahli. Hal tersebut diharapkan dapat menyelesaikan permasalahan yang ada, sehingga terwujudnya cita-cita pemerintahan Desa Kolam yakni mewujudkan "Desa Kolam yang Sejahtera.

\section{METODE PELAKSANAAN}

Motode pelaksanaan dilakukan sebagai berikut: melakukan persiapan, tahap persiapan ini melakukan beberapa kegiatan yakninya: (a) sosialisasi program Pengabdian Kepada Masyarakat, dengan Mitra di Desa Kolam; (b) melaksanakan observasi dan mewawancarai Mitra serta melakukan diskusi untuk pemecahan masalah yang ada; (c) penentuan jadwal kegiatan; (d) saling berkomitmen antara pengabdi dengan Mitra; dan (e) mempersiapkan sarana dan prasarana untuk mendukung terlaksananya kegiatan Pengabdian kepada Masyarakat, (f) Focus Group Discussion (FDG) dengan Mitra, (g) pelatihan, pendidikan, dan pendampingan tentang pentingnya pembukuan keuangan dalam suatu usaha, (h) pelatihan, pendidikan, dan pendampingan bagaimana cara pengolahan pakan menggunakan inovasi mesin pengolahan pakan, dan (i) serah terima mesin Teknologi Tepat Guna (TTG).

\section{HASIL DAN PEMBAHASAN}

Kegiatan Pengabdian Kepada Masyarakat ini menghasilkan luaran sebagai berikut: 1) buku panduan pembukuan keuangan, dan 2) inovasi mesin pengolahan pakan ternak.

Berikut produk yang dihasilkan selama kegiatan pengabdian kepada masyarakat dilakukan:

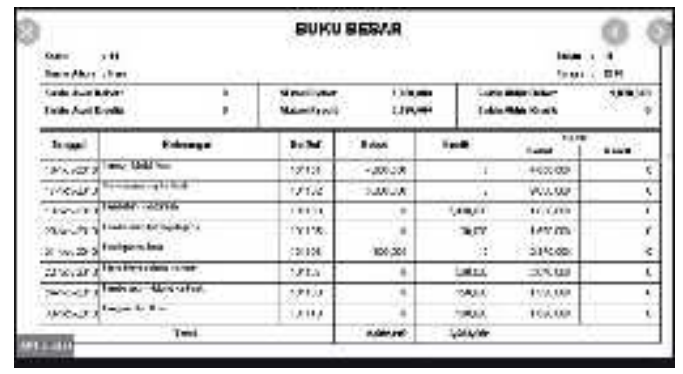

Gambar 1. Buku Panduan Laporan Keuangan yang Sudah Tersusun Rapi.

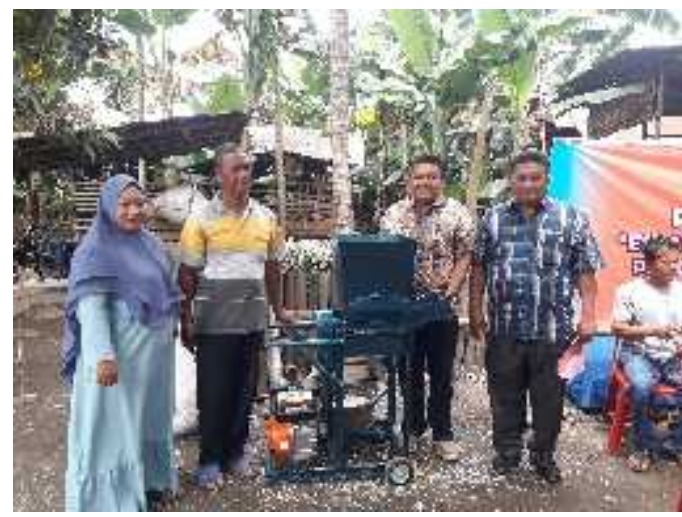

Gambar 2. Inovas Mesin Teknologi

Tepat Guna (TTG) Mesin

Pengolahan Pakan.

Beberapa kepakaran yang dibutuhkan dalam pencapaian hasil kegiatan yang maksimal sebagai berikut: 1) Ahli Pembukuan Keuangan Rasional: dalam kegiatan pelatihan, pendidikan, dan pendampingan yang dilakukan pada Usaha Susu Kambing Etawa di Kecamatan Percut Sei Tuan Kabupaten Deli Serdang tentang penyusunan laporan keuangan, maka dengan itu perlu didatangkan pakar dalam bidang 
ekonomi, terkhusus perekonomian usaha kecil menengah dan 2) Ahli Desain Inovasi Mesin Pengolahan Pakan Ternak dengan rasional: dalam upaya mendesain inovasi mesin pengolahan pakan Usaha Susu Kambing Etawa di Kecamatan Percut Sei Tuan Kaupaten Deli Serdang perlu adanya pelatihan, pendidikan, pendampingan, dan sosialisasi yang langsung mendatangkan pakar dari Teknik Mesin.

\section{KESIMPULAN}

Kegiatan Pengabdian kepada Masyarakat ini bertujuan untuk meningkatkan kualitas pembukuan keuangan dan kualitas pengolahan pakan pada usaha mitra yaitunya usaha susu kambing etawa di Kecamatan Percut Sei Tuan Kabupaten Deli Serdang. Permasalahan yang dihadapi oleh Mitra di sini yaitu; (1) pengelolaan keuangan bisa dikatakan belum maksimal dimana hanya menggunakan kertas bekas, penghitungannyapun hanya bersifat gali lobang tutup lobang (tidak ada perhitungan modal dan laba, tidak jarang modal dan laba digunakan untuk keperluan lain) dan (2) pengolahan pakan ternak yang masih manual yaitu menggunakan tenaga manusia.

Solusi yang ditawarkan di sini, Mitra diberikan pelatihan, pendidikan, pendampingan, sosialisai, dan penyerahan Teknologi Tepat Guna (TTG) mengenai permasalahan yang dihadapi oleh Mitra. Target khusus yang telah dicapai dalam pengabdian ini yaitu: (1) panduan pembukuan keuangan dan pembukuan keuangan menggunakan buku besar yang dirancang untuk menghitung keuangan usaha sudah baik dan benar dan (2) serah terima mesin inovasi Teknologi Tepat Guna (TTG) pengolahan pakan ternak. Metode pelaksanaan program pengabdian dilakukan secara berjenjang, berkesinambungan, dan komprehensif yang dilaksanakan melalui metode pendekatan. Pendekatan di sini dimaksudkan adalah perolehan informasi awal hingga proses kegiatan dilakukan dengan komunikasi secara langsung atau lewat alat komunikasi secara intensif dengan Mitra, sehingga pelaksanaan kegiatan dapat dilakukan secara terbimbing, dengan tujuan utama untuk meningkatkan kesejahteraan Mitra dalam mengelolah Usaha Kecil Menengah (UKM)nya, yaitu usaha susu kambing etawa di Kecamatan Percut Sei Tuan Kabupaten Deli Serdang.

\section{REFERENSI}

Yuni, Revita. (2018). Pemberdayaan Usaha Kecil Menengah (UKM) di Desa Kolam. Medan: LPPM Unimed.

Undang-Undang. (2014). UndangUndang Desa Nomor 6: Jakarta. 